\title{
The Effects of Gender on Attitudes of Preservice Teachers towards the Teaching Profession: A Meta-analysis Study
}

\author{
Gürcü Erdamar ${ }^{1, *}$, Tufan Aytaç ${ }^{2}$, Nilay Türk ${ }^{3}$, Zeynep Arseven ${ }^{4}$ \\ ${ }^{1}$ Faculty of Education, Gazi University, Turkey \\ ${ }^{2}$ Faculty of Education, Bozok University, Turkey \\ ${ }^{3}$ MEB Teacher Mehmet Ali Durak Secondary School, Turkey \\ ${ }^{4}$ Faculty of Education, Duzce University, Turkey
}

Copyright $(\subset 2016$ by authors, all rights reserved. Authors agree that this article remains permanently open access under the terms of the Creative Commons Attribution License 4.0 International License

\begin{abstract}
The aim of this study is to define the effects of gender on attitudes of preservice teachers towards the teaching profession in Turkey. It combines the findings of 35 relevant studies comprising a sample of 4,289 male and 6,073 female preservice teachers. A Group Difference model was used to identify fixed and random effects and to facilitate comparison using meta-analysis methods. A significant effect size $(\mathrm{d}=0.271)$ on an insignificant level was identified in favour of the gender attitudes of female preservice teachers. The location of the research, branch, and class level/educational status were also found to have moderating effects on attitudes.
\end{abstract}

Keywords Gender, Meta-analysis, Preservice Teachers, Professional Attitude

\section{Introduction}

Education continues to be a key investment in communities striving to raise individuals that can thrive within a knowledgeable and informed society. However, a major challenge for many of today's education systems remains how to effectively cohere the objectives of teachers, students, and curriculums. Deficit in any of these areas, or factors, directly affects the education process. The relations between such systemic factors are also important given that traditionally the influence of teachers on students and curriculums are higher than the others [1]. Since the quality and standard of education are majorly proportionate to the qualities of teachers, their proper training before service and in service is essential [2]. The success of an education system depends on the quality and the quantity of the teachers who will manage the system [3].

Recently, it has been observed that important structuring processes occur during teacher training. However, in the background to several studies, there are the criticisms towards teacher training programs, and therefore, the aim of raising qualified teachers [4]. In the training of qualified teachers, perspectives of preservice teachers towards the occupation take an important place. In the emergence of the perspectives of preservice teachers towards the occupation, the programs that train them have important effects [5]. Teachers can perform their expected roles effectively to the extent that they recognize themselves and their occupation in pre-service training [6]. Determinants of the occupational behaviours of teachers are their attitudes towards their occupation. The way that teachers perceive their occupation will reflect their "perception of the teaching profession." Therefore, the learning experience of preservice teachers provides a basis for the creation of their occupational perception [7].

Teachers help students to acquire some behaviour by becoming role models with their knowledge, attitudes, behaviours, and personalities. Within this process, among the qualities that teachers have to possess, there are general knowledge, field information and professional teaching knowledge, as well as the attitudes they develop towards their occupation $[8,9]$. The attitude of individuals towards their occupations is the most important factor that is effective in their occupational success [10].

Teachers' attitudes towards their occupation indicate that they love their profession; they are attached to it; they reach the awareness that their work is important and necessary for society; and, they believe that they have to improve themselves because of it [11]. Attitudes of teachers towards their occupation also have an important influence on their performance [12]. Positive attitude towards the teaching profession will ensure the coherence of behaviours and emotions when preservice teachers start to perform their duty; and will positively affect all the factors related to teaching [13]. 
Knowing the attitudes of preservice teachers towards their occupation will help their trainers to address them during prevocational training [14]. In this context, studies conducted to identify preservice teachers' Attitudes towards Teaching Profession (ATTP) gain importance.

A number of qualitative and quantitative studies have been conducted on the ATTP of teachers in Turkey. These have used various scales and considered different independent variables (gender, branch, marital status, level of education, the faculty they graduated from, superiority etc.). Together this body of research has produced statistically both significant and insignificant results along with others that show differences between the subgroups of independent variables. Meta-analysis is required to synthesize the findings of this research and to guide future studies concerning the opinions of preservice teachers in relation to ATTP. Tekerek and Polat [15] suggested that since studies conducted on attitudes towards the teaching profession reach different results, to analyse these differences more deeply, different study methods, and more comprehensive and different samples should be used. The fact that the number of the studies about the opinions of teachers on ATTP has increased recently reveals the need for discovering a common result by compiling the results and considering the numbers of samples, and the need for synthesis. As no meta-analysis study on the opinions of preservice teachers on ATTP currently exists in the relevant literature, the findings of this study will help to define the effects of gender on ATTP of preservice teachers and enable researchers to conduct studies in this field within the context of different variables.

\section{Method}

In this study, with the aim of defining the effects of gender on ATTP of preservice teachers, meta-analysis of relevant research was conducted in Turkey.

\section{Pattern of the Research}

Being one of the methods to synthesize research results, meta-analysis informs the pattern of this research and involves analysis, synthesis, and interpretation of the quantitative findings acquired from independent studies through advanced statistical techniques. The aim of a meta-analysis is to unite the findings acquired from studies conducted on the same subject in different places and times and to reach quantitatively the truest through increasing the number of samples [16-19].

\section{Data Collection Tool}

Master theses, Ph.D. dissertations, and articles about the ATTP of preservice teachers in Turkey constitute the basic data source of this research. To access the relevant studies, a search was conducted using the key words "attitude towards teaching profession," "opinions towards teaching profession," and "attitude towards the teaching profession". A variety of databases was consulted including the YOK National Thesis Archive, EBSCO, Sciencedirect, Proquest, Tübitak ULAKBIM, Web of Science, ERIC and Google Scholar. All relevant studies undertook until February 2015 were noted. In the selection of the included studies, the following inclusion criteria were adopted [16, 20];

Research methods used in the studies should be appropriate, and the studies should include the necessary statistical data for meta-analysis,

1. They should be published or unpublished M.A. theses, Ph.D. dissertations, and research articles,

2. Sample group should consist of preservice teachers,

3. Validity and reliability data of the measuring tools should be given.

Within the scope of the above-given, the data concerning the number and sample sizes of the included studies are given in Table 1. Among the studies identified from the initial search, 35 studies were selected for meta-analysis within the context of the gender variable.

Table 1. Number and Sample Sizes of the Studies Included in the Meta-Analysis

\begin{tabular}{cccccccccc}
\hline & \multicolumn{4}{c}{ Gender } & \multicolumn{4}{c}{ Study Type } \\
\cline { 2 - 9 } ATTP & Number of Studies & Female & Male & Total & $\begin{array}{c}\text { Number of } \\
\text { Studies }\end{array}$ & $\begin{array}{c}\text { Postgraduate } \\
\text { Thesis }\end{array}$ & Article & Total \\
\cline { 2 - 9 } & 35 & 6073 & 4298 & 10371 & 35 & 11 & 24 & 35 \\
\hline
\end{tabular}


After the scan of the literature, it was determined that from 60 studies conducted on the research topic, 35 studies met the inclusion criteria. As this body of research was carried out on different samples (teachers, faculty members, students of teacher high school) and did not have the necessary statistical data for meta-analysis, 25 studies were not included in the research. The sample of this research is limited to the data of 11 M.A. theses and Ph.D. dissertations, and 24 research articles conducted in Turkey on this subject between the years 2004 and 2015.

Reliability of the Research: In the research, before the meta-analysis, to decide the studies to be included in the meta-analysis, a coding protocol concerning the identity, content, and data of the research was created. The year of the research, branches of teachers, gender of the researcher, location of the research, sample group, educational level, publication type, sample size, validity and reliability proof of the used measuring tools, sample size with regard to seniority/gender variables, average standard deviation, $\mathrm{F}$ value, $\mathrm{t}$ value, $\mathrm{X}^{2}$ value, Kruskal Wallis value, Mann Whitney $\mathrm{U}$ data, and $\mathrm{p}$ values were keyed in the coding protocol. To ensure the reliability (interrater reliability - IRR) between encoders, an inter-encoder reliability analysis form was used. Coding forms of the researchers were evaluated through a meeting with an Assessment and Evaluation expert and an evaluation was made about the studies to be included within the scope of this study. To secure the inter-encoder reliability, Cohen's Kappa statistic was used; and the reliability was found as 0.95 . Such a result demonstrates an almost perfect coherence between encoders.

Validity of the research: In a meta-analysis, the data acquired from written sources are only valid if collection tools are able to measure what they try to measure. The data related to the unified effect size in the meta-analysis are as valid as the studies included in the analysis [21,22]. Validity of the collection tools used in the all studies included in the analysis will ensure the validity in the meta-analysis [18]. In the present study, 35 theses, dissertations, and research articles appropriate to the specified criteria were read, and the validity and reliability of their measuring tools was checked. Therefore, within this context, it can be said that this meta-analysis study is valid.

\section{Analysis of the Data}

In the analysis of the data, according to group comparison meta-analysis methods (fixed effects and random effects models), a Group Difference model is used. In cases that arithmetic mean values of the independent variables in the study were not taken from the same scales, a standardized arithmetic means difference effect size method was used. While the effect size was being calculated, arithmetic means and standard deviations of the body of research on the gender dimension were used. In this study, effect sizes and their variances, and the comparisons of the groups were calculated through the use of statistical Package Program for Meta-Analysis CMA Ver. 2.2.064 [Comprehensive Meta Analysis] [ 16, 18, 23].

A fixed effect model accepts that sizes of the study fields are the same, and, therefore deviation equals to zero. When the assumptions of the fixed effect model are not actualized, a random effects model is used. Thus, a random effects model means that individual sizes of the study fields are different and standard deviation does not equal to zero. This model enables us to make an evaluation by considering the change both within the studies and between the studies. If the study fields in the meta-analysis have the same size, a fixed effect model is used; if they are not, a random effects model is used $[19,24,45]$. If the results of the individual studies included in the meta-analysis are homogenous, a fixed effect model is used; if they are heterogeneous, random effects model is used [24]. In this study, the effect of the moderators, which are predicted to affect the results of the study, was defined with $Q$ test $[17,25]$. Being developed as the complement of the $\mathrm{Q}$ statistics, $\mathrm{I}^{2}$ reveals a clearer result concerning to heterogeneity. $\mathrm{I}^{2}$ demonstrates the rate of total variance about effect size. Unlike Q statistics, $\mathrm{I}^{2}$ statistics is not affected by the number of studies. In the evaluation of the $\mathrm{I}^{2}, 25 \%$ indicates a low level of heterogeneity; $50 \%$ indicates a moderate level of heterogeneity; and, $75 \%$ indicates a high level of heterogeneity [26]. In the study, female teachers were the experimental group, and male teachers were the control group. Therefore, it is interpreted that if the calculated effect size is positive, it is for the benefit of females; and if the calculated effect size is negative, it is for the benefit of males.

\section{Results}

The results acquired as a result of the analysis made with the aim of answering the problem of the research, publication bias, descrpitive statistics, forest plot, findings of fixed and random effects models, homogeneity test, and results related to moderator analysis stated.

\section{The Effects of Gender on ATTP of Preservice Teachers}

As the aim of this study was to define the effects of gender on ATTP of preservice teachers, it was necessary to establish whether each study included publication bias or not, prior to the effect size being defined. Showing the possibility of the publication bias, the results of the funnel scatter plot are given in Figure 1. 


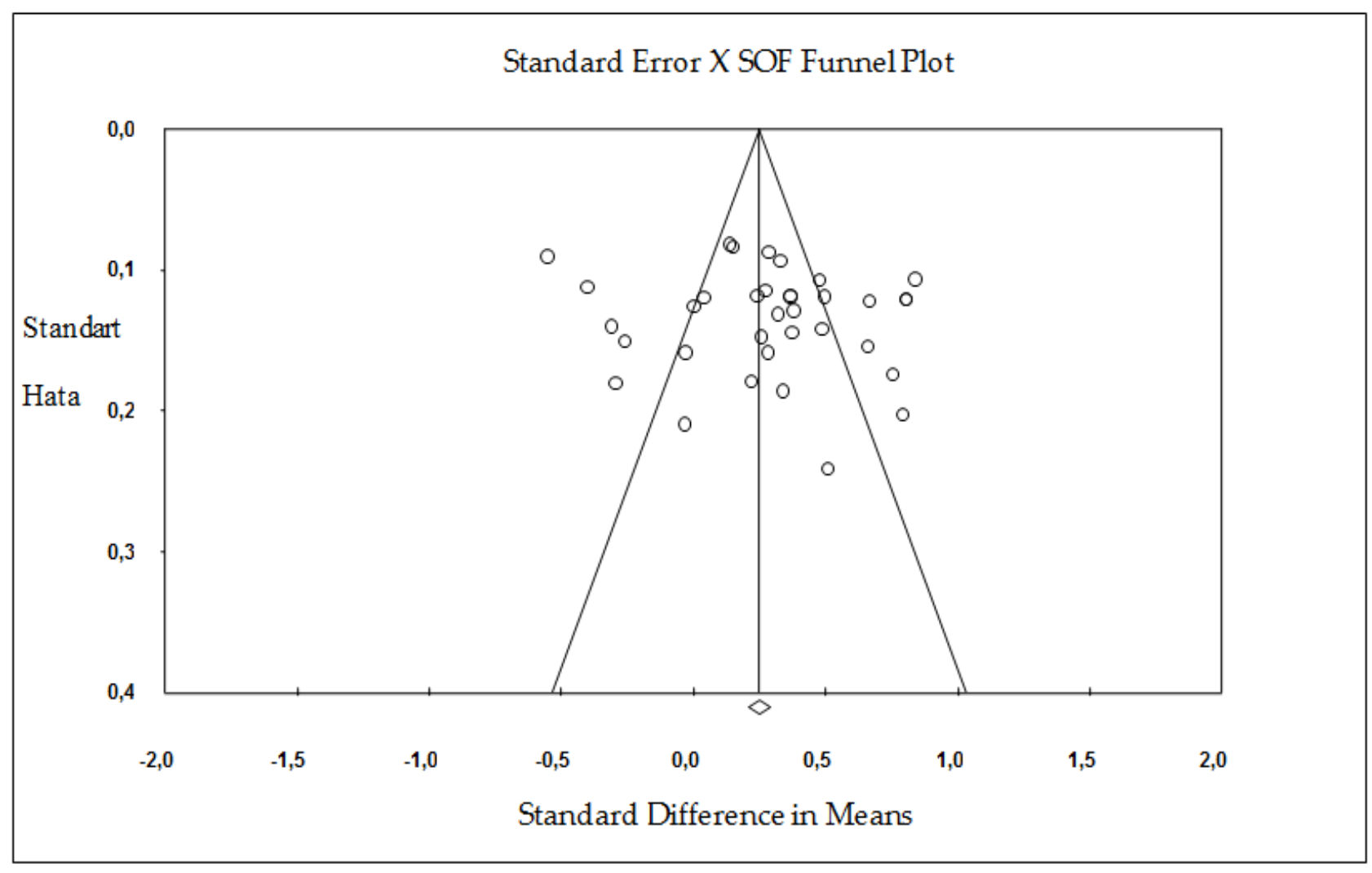

Figure 1. Funnel Scatter Plot With Regard to Gender Variable

As observed in the Figure 1, most of the 35 studies included in the research are situated towards the upper part of the shape and in a close position to the combined effect size. In cases that there is not publication bias, studies are expected to expand symmetrically along both sides of the vertical line, which shows the unified effect size. If there were publication bias in the 35 studies included in the research, most of the studies would be accumulated at the bottom of the funnel shape and/or only at one side of the vertical line [23]. In this sense, a funnel-shaped scatter plot displays that there is not publication bias with regard to the studies included in the research.

To test publication bias, Orwin's Fail-Safe N calculation was also made. Orwin's Fail-Safe N calculates the number of studies that may be lacking in a meta-analysis [23]. As a result of this analysis, Orwin's Fail-Safe N is calculated as 138. For the average effect size, which was found as 0.247 as a result of the meta-analysis, to reach the level of 0.01 (trivial) - to reach almost zero effect level - the necessary number of studies is 138. However, 35 studies, specified in accordance with the inclusion criteria, are the entire number of studies (qualitative, quantitative, theoretical, etc.) conducted on this subject in Turkey. Since it is not possible to access 138 studies, this result is considered as another indicator, which proves that there is not publication bias in this meta-analysis. Also, it is observed that Kendall's Tau coefficient, which is used to statistically calculate whether there is publication bias or not, is 0.006 and $p=0.95$; in such case, since $\mathrm{p}$ value does not create a significant difference - since it satisfies the expectation of being more than $0.05-$ it is statistically proven that there is not publication bias.

\section{Uncombined Findings of the Effect Size Analysis With Regar d to the Genders of Preservice Teachers}

Effect sizes, standard error, and lower and upper limits of opinions of male and female preservice teachers concerning ATTP are given in Table 2, in accordance with 95\% confidence interval.

According to Table 2, standardized means difference (SMD) of these 35 studies differs between the interval of -0.347 for the benefit of male teachers, and 0.486 for the benefit of female teachers. While statistically significant differences $(p<0.05)$ are found in twenty-two studies, in 13 studies, no significant difference is found. The confidence interval of thirty-five studies differs between -0.833 and 1.907. 
Table 2. Effect Sizes of Preservice Teachers' Opinions Concerning ATTP With Regard to Their Gender

\begin{tabular}{|c|c|c|c|c|c|c|c|c|c|c|}
\hline Model & Name of the Study & $\begin{array}{l}\text { Effect } \\
\text { Size (d) }\end{array}$ & $\begin{array}{c}\text { Standard } \\
\text { error }\end{array}$ & Variance & $\begin{array}{c}\text { Lower } \\
\text { limit }\end{array}$ & $\begin{array}{l}\text { Upper } \\
\text { limit }\end{array}$ & Z-Value & p-Value & $\begin{array}{l}\text { Number of } \\
\text { Female }\end{array}$ & $\begin{array}{l}\text { Sample } \\
\text { Male }\end{array}$ \\
\hline & Ak1llı and Seven, $2010^{8}$ & 0.221 & 0.180 & 0.032 & -0.131 & 0.573 & 1.229 & 0.219 & 60 & 65 \\
\hline & Akkaya, $2009^{27}$ & 0.488 & 0.142 & 0.020 & 0.209 & 0.766 & 3.436 & 0.001 & 147 & 78 \\
\hline & Akpinar et al., $2006^{28}$ & 0.368 & 0.119 & 0.014 & 0.134 & 0.602 & 3.083 & 0.002 & 151 & 135 \\
\hline & Aydın and Sağlam, $2012^{29}$ & 0.382 & 0.129 & 0.017 & 0.129 & 0.636 & 2.955 & 0.003 & 132 & 113 \\
\hline & Bulut, $2011^{30}$ & 0.242 & 0.119 & 0.014 & 0.009 & 0.475 & 2.036 & 0.042 & 171 & 122 \\
\hline & Çeliköz, $2010^{31}$ & 0.339 & 0.186 & 0.035 & -0.026 & 0.704 & 1.821 & 0.069 & 434 & 31 \\
\hline & Çapri and Çelikkaleli, $2008^{32}$ & 0.321 & 0.132 & 0.017 & 0.062 & 0.580 & 2.433 & 0.015 & 92 & 158 \\
\hline & Çetinkaya, $2007^{33}$ & 0.369 & 0.119 & 0.014 & 0.136 & 0.602 & 3.104 & 0.002 & 120 & 180 \\
\hline & Çetinkaya, $2009^{34}$ & 0.662 & 0.154 & 0.024 & 0.359 & 0.965 & 4.286 & 0.000 & 128 & 67 \\
\hline & Çiçek Sağlam ,2008 ${ }^{35}$ & 0.793 & 0.203 & 0.041 & 0.395 & 1.191 & 3.905 & 0.000 & 64 & 44 \\
\hline & Çiğdem and Memiş, $2007^{36}$ & 0.806 & 0.121 & 0.015 & 0.568 & 1.044 & 6.644 & 0.000 & 268 & 99 \\
\hline & Çiğdem, $2010^{37}$ & 0.806 & 0.121 & 0.015 & 0.568 & 1.044 & 6.644 & 0.000 & 268 & 99 \\
\hline & Dağ, $2010^{38}$ & 0.667 & 0.122 & 0.015 & 0.428 & 0.907 & 5.458 & 0.000 & 208 & 106 \\
\hline & Derman, $2007^{39}$ & -0.513 & 0.113 & 0.013 & -0.735 & -0.292 & -4.547 & 0.000 & 190 & 141 \\
\hline & Dinçer, $2013^{24}$ & -0.028 & 0.159 & 0.025 & -0.339 & 0.284 & -0.173 & 0.863 & 58 & 124 \\
\hline & Gür and Güneş, 2012 ${ }^{40}$ & -0.655 & 0.091 & 0.008 & -0.833 & -0.477 & -7.229 & 0.000 & 311 & 218 \\
\hline & Gökçe and Sezer, $2012^{41}$ & 0.331 & 0.094 & 0.009 & 0.146 & 0.515 & 3.513 & 0.000 & 371 & 165 \\
\hline & Gülsoy, $2010^{42}$ & -0.293 & 0.181 & 0.033 & -0.647 & 0.061 & -1.624 & 0.104 & 63 & 61 \\
\hline & $\begin{array}{l}\text { Hacıömeroğlu and Taşkın, } \\
2010^{5}\end{array}$ & -0.030 & 0.210 & 0.044 & -0.442 & 0.381 & -0.144 & 0.885 & 32 & 78 \\
\hline & Kartal et al., $2012^{43}$ & -0.259 & 0.151 & 0.023 & -0.554 & 0.037 & -1.715 & 0.086 & 95 & 83 \\
\hline & Kaya, $2004^{44}$ & 0.152 & 0.084 & 0.007 & -0.013 & 0.316 & 1.809 & 0.070 & 224 & 392 \\
\hline & Ertok Konuk, 2011 ${ }^{45}$ & 0.139 & 0.082 & 0.007 & -0.022 & 0.300 & 1.698 & 0.090 & 400 & 237 \\
\hline & $\begin{array}{l}\text { Oğuz and Kalkan, } 2011^{46} \\
\text { Özder. Konedralı }\end{array}$ & 0.005 & 0.126 & 0.016 & -0.243 & 0.253 & 0.037 & 0.970 & 187 & 94 \\
\hline & $2010^{47}$ & 0.260 & 0.148 & 0.022 & -0.030 & 0.549 & 1.756 & 0.079 & 139 & 69 \\
\hline & Pehlivan, $2010^{48}$ & 0.274 & 0.115 & 0.013 & 0.048 & 0.500 & 2.380 & 0.017 & 163 & 143 \\
\hline & Pektaş and Kamer, $2011^{49}$ & 0.480 & 0.108 & 0.012 & 0.269 & 0.690 & 4.457 & 0.000 & 242 & 140 \\
\hline & Serin et al., $2004^{50}$ & -0.307 & 0.141 & 0.020 & -0.583 & -0.032 & -2.184 & 0.029 & 112 & 94 \\
\hline & Sezer et al. $2010^{51}$ & 0.499 & 0.119 & 0.014 & 0.265 & 0.733 & 4.179 & 0.000 & 130 & 163 \\
\hline & Tanel et al., $2007^{52}$ & 0.285 & 0.159 & 0.025 & -0.027 & 0.596 & 1.792 & 0.073 & 78 & 82 \\
\hline & Tekerek and Polat, $2011^{15}$ & 0.375 & 0.145 & 0.021 & 0.090 & 0.659 & 2.583 & 0.010 & 88 & 107 \\
\hline & Tekneci, $2010^{53}$ & 0.842 & 0.107 & 0.011 & 0.632 & 1.051 & 7.880 & 0.000 & 261 & 149 \\
\hline & $\begin{array}{l}\text { Uğurlu and Polat, } 2011^{54} \\
\text { Üstüner Demirtas and }\end{array}$ & 0.041 & 0.120 & 0.014 & -0.193 & 0.276 & 0.344 & 0.731 & 221 & 102 \\
\hline & Cömert, $2009^{55}$ & 0.287 & 0.088 & 0.008 & 0.114 & 0.459 & 3.261 & 0.001 & 262 & 261 \\
\hline & Yeşil, $2011^{56}$ & 0.755 & 0.174 & 0.030 & 0.413 & 1.097 & 4.330 & 0.000 & 60 & 85 \\
\hline & Y1lmaz, $2009^{57}$ & 0.509 & 0.291 & 0.085 & -0.061 & 1.080 & 1.750 & 0.080 & 143 & 13 \\
\hline Fixed & & 0.247 & 0.021 & 0.000 & 0.206 & 0.288 & 11.722 & 0.000 & 6073 & 4298 \\
\hline Random & & 0.271 & 0.066 & 0.004 & 0.142 & 0.401 & 4.122 & 0.000 & 6073 & 4298 \\
\hline
\end{tabular}




\begin{tabular}{|c|c|c|c|c|c|c|c|}
\hline \multirow[t]{2}{*}{ Study name } & \multicolumn{7}{|c|}{ Statistics for each study } \\
\hline & $\begin{array}{l}\text { Std diff } \\
\text { in means }\end{array}$ & $\begin{array}{c}\text { Standard } \\
\text { error }\end{array}$ & Variance & $\begin{array}{r}\text { Lower } \\
\text { limit }\end{array}$ & $\begin{array}{r}\text { Upper } \\
\text { limit }\end{array}$ & Z-Value & p-Value \\
\hline Akýllý ve Seven, 2010 & 0,221 & 0,180 & 0,032 & $-0,131$ & 0,573 & 1,229 & $0,21 \subseteq$ \\
\hline Akkaya ,2009 & 0,488 & 0,142 & $0,02 \mathrm{C}$ & 0,209 & 0,760 & 3,436 & 0,001 \\
\hline Akpýnar ve dio. ,200e & 0,368 & 0,119 & 0,014 & 0,134 & 0,602 & 3,083 & 0,002 \\
\hline Aydýn ve Saб̄lam, 2012 & 0,382 & 0,129 & 0,017 & 0,129 & 0,630 & 2,955 & $0,00 \Xi$ \\
\hline Bulut, 2011 & 0,242 & 0,119 & 0,014 & 0,009 & 0,475 & 2,036 & 0,042 \\
\hline Çeliközz, 2010 & 0,339 & $0,18 \theta$ & $0,03 E$ & $-0,02 \theta$ & 0,704 & 1,821 & 0,085 \\
\hline Çepri ve Çelìkkaleli, 2008 & 0,321 & 0,132 & 0,017 & 0,062 & 0,580 & 2,433 & $0,01 E$ \\
\hline Cetinkays, 2007 & 0,389 & 0,119 & 0,014 & 0,136 & 0,602 & 3,104 & 0,002 \\
\hline Cetinkays, 2009 & 0,682 & 0,154 & 0,024 & 0,359 & 0,985 & 4,286 & $0,00 \mathrm{C}$ \\
\hline Çiçek Sab̂lam ,2008 & 0,793 & 0,203 & 0,041 & 0,395 & 1,191 & 3,905 & \\
\hline Çiốdem ve Memip, 2007 & 0,806 & 0,121 & $0,01 E$ & 0,588 & 1,044 & 6,644 & $0,00 \mathrm{C}$ \\
\hline Çiödem, 2010 & $0,80 \theta$ & 0,121 & $0,01 E$ & 0,588 & 1,044 & 6,644 & $0,00 \mathrm{C}$ \\
\hline Dab, 2010 & 0,687 & 0,122 & $0,01 E$ & 0,428 & 0,907 & 5,458 & $0,00 \mathrm{C}$ \\
\hline Derman, 2007 & $-0,513$ & 0,113 & 0,013 & $-0,735$ & $-0,292$ & $-4,547$ & $0,00 \mathrm{C}$ \\
\hline Dincer, 2013 & $-0,028$ & 0,159 & $0,02 E$ & $-0,339$ & 0,284 & -0 , & 0,868 \\
\hline Gür ve Gūnes , 2012 & $-0,655$ & 0,091 & $0,00 \varepsilon$ & $-0,833$ & $-0,477$ & -7 & $0,00 \mathrm{C}$ \\
\hline Gökçe ve Sezer, 2012 & & & $0,00 \subseteq$ & 0,146 & 0,515 & & \\
\hline Gülsoy, 2010 & $-0,2$ & & .032 & $-0,647$ & 0.0 & & \\
\hline Hacjömeroőlu ve Tapkýn, 2010 & $-0,030$ & & 0,044 & $-0,442$ & 0,381 & & \\
\hline Kartal ve dio., 2012 & $-0,259$ & & $0,02 z$ & $-0,554$ & 0,037 & $-1,715$ & $0,08 \epsilon$ \\
\hline Кауя, 2004 & & & 0,007 & $-0,013$ & 0,316 & 1,809 & $0,07 \mathrm{C}$ \\
\hline Konuk, 2011 & 0,139 & 0,082 & 0,007 & $-0,022$ & 0,300 & 1,698 & $0,09 \mathrm{C}$ \\
\hline O6uz ve Kakan, 2011 & 0,005 & $0,12 \theta$ & $0,01 \epsilon$ & $-0,243$ & 0,253 & & \\
\hline Ozder, Konedralý ve Zeki, 2010 & 0,260 & & $0,02 z$ & $-0,030$ & 0,549 & 1,756 & 0,07 ? \\
\hline Pehlivan, 2010 & 0.274 & 0,115 & $0,01 \Xi$ & 0,048 & 0,500 & 2,380 & 0,017 \\
\hline Pektap ve Kamer, 2011 & 0,480 & 0,108 & 0,012 & 0,269 & 0,690 & 4,457 & $0,00 \mathrm{C}$ \\
\hline Serin ve dio. ,2004 & $-0,307$ & 0,141 & $0,02 \mathrm{C}$ & $-0,583$ & $-0,032$ & $-2,184$ & $0,02 \mathrm{E}$ \\
\hline Sezer ve dio. ,2010 & 0,499 & 0.119 & 0,014 & 0,265 & 0,733 & 4,179 & $0,00 \mathrm{C}$ \\
\hline Tanel ve dio. ,2007 & 0,285 & 0,159 & $0,02 E$ & $-0,027$ & 0,590 & 1,792 & $0,07:$ \\
\hline Tekerek- Polat ,2011 & 0,375 & 0,145 & 0,021 & 0,090 & 0,659 & 2,583 & $0,01 \mathrm{C}$ \\
\hline Tekneci, 2010 & 0,842 & 0,107 & 0,011 & 0,632 & 1,051 & 7,880 & $0,00 \mathrm{C}$ \\
\hline U6̆urlu ve Polat, 2011 & 0,041 & 0,120 & 0,014 & $-0,193$ & $0,27 \theta$ & 0,344 & 0,731 \\
\hline Üstüner, Demirtaş ve Cömert, 200 & 090,287 & 0,088 & 0,008 & 0,114 & 0,459 & 3,281 & 0,001 \\
\hline Yepil, 2011 & 0,755 & 0,174 & $0,03 C$ & 0,413 & 1,097 & 4,330 & $0,00 \mathrm{C}$ \\
\hline Yýlmez, 2009 & 0,509 & 0,291 & $0,08 E$ & $-0,061$ & 1,080 & 1,750 & $0,08 \mathrm{C}$ \\
\hline & 0,247 & 0,021 & $0,00 C$ & 0,200 & 0,288 & 11,727 & $0,00 \mathrm{C}$ \\
\hline
\end{tabular}

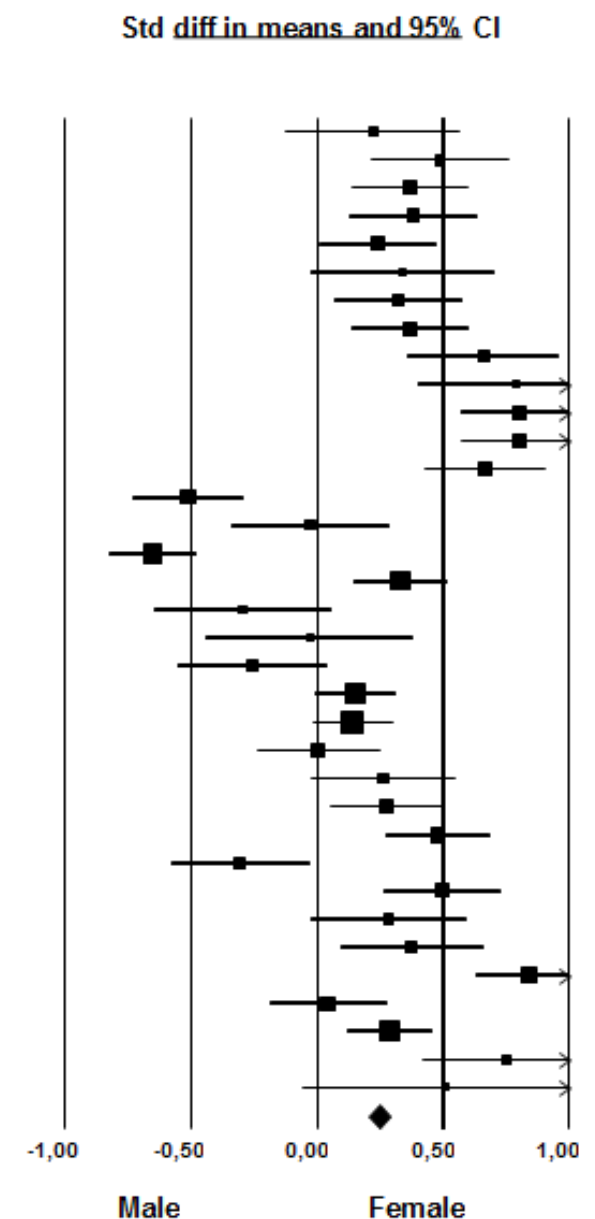

Figure 2. Forest Plot of the Effect Sizes Related to the Gender Variable

Forest Plot of the Studies in relation to the gender variable.

A forest plot related to the 35 studies that include data about the gender variable is displayed in Figure 2.

When Figure 2 is analysed, it is observed that there is a difference more than zero for the benefit of female preservice teachers. The fact that there is a difference for the benefit of female preservice teachers can be interpreted as such that their ATTPs are more positive compared to male preservice teachers.

\section{Findings of Effect Size Meta-Analysis Related to the Gender of Preservice Teachers Which Are Combined In Accordance With the Fixed and Random Effects Models}

Combined in accordance with the fixed and random effects model, the average effect size (without excluding outliers) of the effect sizes of the perceptions of female and male preservice teachers with regard to ATTP; standard error; and the lower and the upper limits in accordance with $95 \%$ confidence interval are given in Table 3.

Table 3. Findings of Effect Size Meta-Analysis Related to Gender Variable Which Are Combined In Accordance With Fixed and Random Effects Models and Homogeneity Test

\begin{tabular}{|c|c|c|c|c|c|c|c|c|c|c|}
\hline \multirow[t]{2}{*}{ Model } & \multicolumn{6}{|c|}{ Effect Size and 95\% confidence interval } & \multicolumn{3}{|c|}{ Heterogeneity } & \multirow[b]{2}{*}{$I^{2}$} \\
\hline & $\begin{array}{c}\text { Number } \\
\text { of } \\
\text { Studies }\end{array}$ & $\begin{array}{c}\text { Effect } \\
\text { Size }\end{array}$ & $\begin{array}{l}\text { Standard } \\
\text { error }\end{array}$ & Variance & $\begin{array}{l}\text { Lower } \\
\text { limit }\end{array}$ & Upper limit & Z-value & Q-value & $\begin{array}{l}\text { df } \\
(\mathrm{Q})\end{array}$ & \\
\hline Fixed Effects & 35 & 0.247 & 0.021 & 0.000 & 0.206 & 0.288 & 11.727 & 321.802 & 34 & 89.415 \\
\hline Random Effects & 35 & 0.271 & 0.066 & 0.004 & 0.055 & 0.401 & 4.122 & & & \\
\hline
\end{tabular}


According to fixed effects model, the average effect size value of the effect size values of the studies included in the research in accordance with the gender variable is calculated as $d=0.247$ and the average effect size value based on the random effects model is calculated as $\mathrm{d}=0.271$ (Table 2). In accordance with these calculations, data of the 35 studies included in the meta-analysis demonstrate that according to fixed and random effects models, ATTPs of female preservice teachers are more positive than males. Since the effect size value is between $0.20-0.50$, it is observed that according to the classification of Cohen and Lipsey, there is a low level of effect size [58]. According to the classification (0.15-0.40) of Thalheimer and Cook [59], a lower level of difference is observed.

When statistical significance is calculated in accordance with the $\mathrm{Z}$ test, $\mathrm{Z}$ is found as 4.122 . It is determined that the acquired result has a statistical significance with $\mathrm{p}=0.005$. For the homogeneity test, in other words for Q statistics, Q is calculated as 321.802. In chi square table, on a $95 \%$ significance level, 34 degrees of freedom value is found as 49.802. Since the $\mathrm{Q}$ statistics value $(\mathrm{Q}=321.802)$ exceeds 34 degrees of freedom and the critical value of chi square distribution $\left(\mathrm{x}^{2} 0,95=49,802\right)$, the hypothesis with regard to the absence of homogeneity of the distribution of effect sizes are rejected in the fixed effects model. Therefore, it is determined that the distribution of effect sizes has a heterogeneous characteristic in accordance with the fixed effects model.

As a complement to the Q statistics, $\mathrm{I}^{2}$ reveals a clearer result with regard to heterogeneity $[19,22]$. $\mathrm{I}^{2}$ demonstrates the rate of the total variance with regard to effect size. Unlike Q statistics, $I^{2}$ statistics are not affected by the number of the studies. In evaluation of $\mathrm{I}^{2}, 25 \%$ indicates a low level of heterogeneity; $50 \%$ indicates a moderate level of heterogeneity; and, $75 \%$ indicates a high level of heterogeneity [22]. As a result of the homogeneity tests (Q and $\mathrm{I}^{2}$ ) conducted on the gender variable, and since there is heterogeneity between studies, which is close to the high level, the model for the combination process was converted to a random model. The results of moderator analysis, which was carried out to reveal the reasons for this heterogeneity, are given in Table 4.

Table 4. Categorical Moderator Results With Regard to the Effect of Gender towards the ATTPs of Preservice Teachers

\begin{tabular}{|c|c|c|c|c|c|}
\hline Moderator & $\mathrm{k}$ & d & $\mathrm{SE}$ & $95 \% \mathrm{CI}$ & Q \\
\hline $\begin{array}{l}\text { Publication Type } \\
\text { M.A. } \\
\text { Ph.D. } \\
\text { Article } \\
\end{array}$ & $\begin{array}{c}9 \\
2 \\
24 \\
\end{array}$ & $\begin{array}{c}0.415 \\
-0.086 \\
0.236 \\
\end{array}$ & $\begin{array}{l}0.043 \\
0.066 \\
0.026 \\
\end{array}$ & $\begin{array}{c}{[0.331 ; 0.499]} \\
{[-0.216 ; 0.044]} \\
{[0.185 ; 0.287]} \\
\end{array}$ & 40.761 \\
\hline $\begin{array}{c}\text { Location of the Research } \\
\text { Eastern Anatolia } \\
\text { Aegean } \\
\text { Southeastern } \\
\text { Central Anatolia } \\
\text { Central Anatolia /Black sea } \\
\text { Black sea } \\
\text { Marmara } \\
\text { Marmara/ Central Anatolia }\end{array}$ & $\begin{array}{l}4 \\
9 \\
3 \\
5 \\
3 \\
3 \\
3 \\
3 \\
5\end{array}$ & $\begin{array}{c}0.213 \\
0.325 \\
0.591 \\
-0.194 \\
0.268 \\
0.553 \\
0.233 \\
0.240 \\
\end{array}$ & $\begin{array}{l}0.060 \\
0.045 \\
0.098 \\
0.059 \\
0.058 \\
0.071 \\
0.071 \\
0.050 \\
\end{array}$ & $\begin{array}{c}{[0.095 ; 0.331]} \\
{[0.237 ; 0.414]} \\
{[0.400 ; 0.783]} \\
{[-0.310 ;-0.079]} \\
{[0.154 ; 0.381]} \\
{[0.005 ; 0.693]} \\
{[0.094 ; 0.371]} \\
{[0.142 ; 0.339]} \\
\end{array}$ & 90.669 \\
\hline $\begin{array}{c}\text { Preparing Scale } \\
\text { Prepared } \\
\text { Advanced } \\
\end{array}$ & $\begin{array}{c}32 \\
3 \\
\end{array}$ & $\begin{array}{l}0.248 \\
0.224 \\
\end{array}$ & $\begin{array}{l}0.021 \\
0.116\end{array}$ & $\begin{array}{c}{[0.206 ; 0.290]} \\
{[-0.004 ; 0.452]}\end{array}$ & 0.040 \\
\hline $\begin{array}{c}\text { Branch of the Preservice Teacher } \\
\text { Pre-school } \\
\text { Classroom } \\
\text { Branch } \\
\end{array}$ & $\begin{array}{c}4 \\
5 \\
26 \\
\end{array}$ & $\begin{array}{l}0.509 \\
0.460 \\
0.174 \\
\end{array}$ & $\begin{array}{l}0.067 \\
0.056 \\
0.024\end{array}$ & $\begin{array}{l}{[0.377 ; 0.641]} \\
{[0.350 ; 0.570]} \\
{[0.127 ; 0.221]} \\
\end{array}$ & 38.748 \\
\hline $\begin{array}{l}\text { Educational Status/Class Level } \\
1^{\text {st }} \text { grade } \\
1^{\text {st }}, 2^{\text {nd }}, 3^{\text {rd }}, 4^{\text {th }} \text { grade } \\
4^{\text {th }} \text { grade } \\
\text { Formation }\end{array}$ & $\begin{array}{c}3 \\
19 \\
10 \\
3\end{array}$ & $\begin{array}{c}-0.194 \\
0.344 \\
0.209 \\
0.223 \\
\end{array}$ & $\begin{array}{l}0.064 \\
0.027 \\
0.044 \\
0.080\end{array}$ & $\begin{array}{l}{[-0.320 ; 0.069]} \\
{[0.291 ; 0.398]} \\
{[0.123 ; 0.295]} \\
{[0.066 ; 0.380]}\end{array}$ & 60.886 \\
\hline
\end{tabular}

NOTE: $\mathrm{k}=$ number of studies, $\mathrm{d}=$ Cohen's d (SOF), $\mathrm{SE}=$ Standard Error $\mathrm{CI}=$ confidence interval, $\mathrm{Q}=$ Heterogeneity between studies, Comparison analyses were made for those studies included in 2 or more subgroups. $* p<.05$ 
As a result of the moderator analysis, it is seen that the effect sizes of the studies differ $(\mathrm{Q}=38,748, p=0,001, p<0,05)$ in accordance to the fields of preservice teachers. It is observed that the ATTPs of female preservice teachers in pre-school and classroom teaching departments are higher compared to preservice teachers in other branches.

The moderator effects of the studies are identified in accordance with the regions of the cities where the research was conducted $(\mathrm{Q}=90,669, p=0,034, p<0,05)$. When the results of the research carried out within the scope of regions are analysed; while the results of research carried out in South-eastern Anatolia and Black Sea Regions (South-eastern Anatolia: 0.591 and Black Sea: 0.553) indicate that there is a high level of effect size result for the benefit of females, in the studies conducted in Central Anatolia Region as sample, the effect size changes for the benefit of males (Central Anatolia: -0.194).

As a result of the moderator analysis, it is identified that the effect sizes of the studies differ $(\mathrm{Q}=60,886, p=0,001$, $p<0,05)$ in accordance with the educational status/class level of preservice teachers. When the educational status/class level of preservice teachers is taken into consideration, it is observed that the ATTPs of especially female preservice teachers increase as their class levels increase.

As a result of the moderator analysis, it is identified that the effect sizes of the studies do not differ $(\mathrm{Q}=0,040$, $p=0,842, p>0,05)$ in accordance with the preparation of scales (prepared or advanced).

Among the independent variables of the studies, which were included in the meta-analysis with regard to gender, Q statistics test were carried out, in accordance with the location of the research, educational status/level, field of teaching, and preparation of scale. As a result of the test, it is identified that apart from the preparation of scale variable, for all other moderators, intergroup distributions are heterogeneous, and the gender of preservice teachers affect the average effect size value.

As observed in Figure 3, with regard to the effect sizes of the research studies; it is observed that over time, there is a tendency of increase in the gender difference for the benefit of female preservice teachers.

\section{Effect Sizes of the 35 Research Studies}

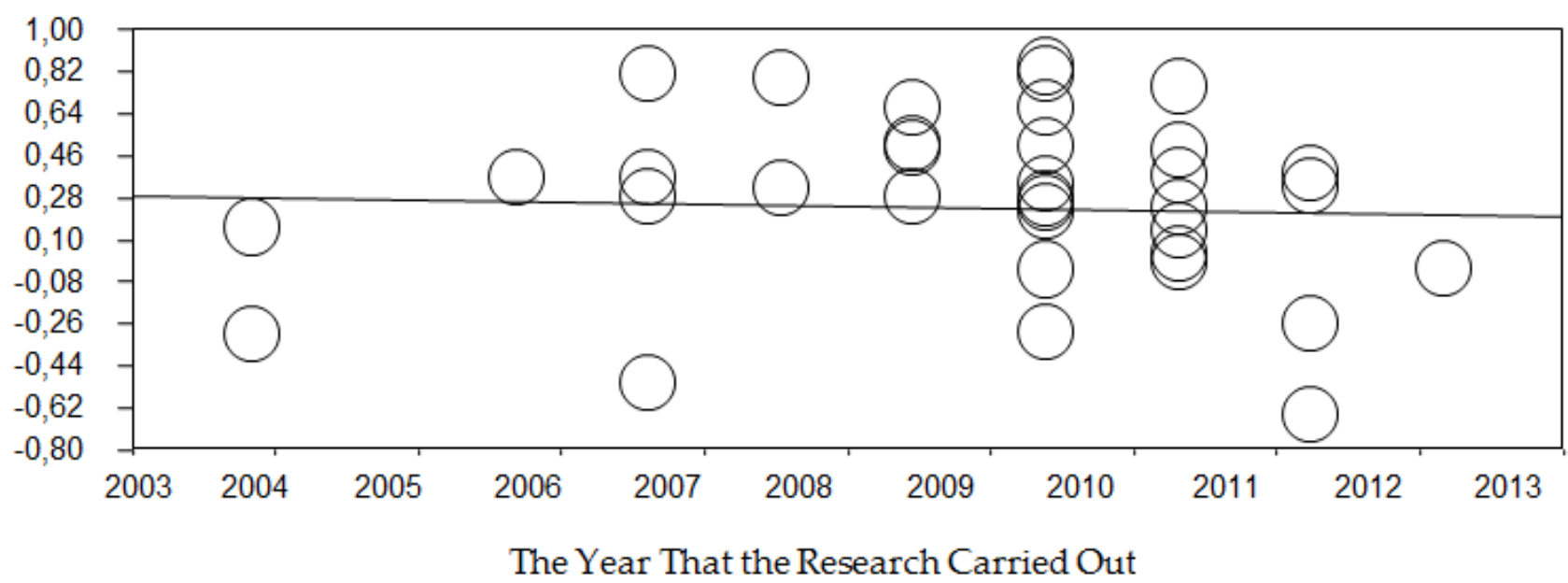

Figure 3. Meta-Regression Results of Effect Sizes Considering the Years That the Research Was Carried Out 


\section{Discussion and Conclusions}

In this study, the effect sizes of 35 studies, which form a sample of 10371 preservice teachers, were calculated. While statistically significant differences were found in 22 of these studies; no significant difference was found in the other 13. As a result of the combination process in the random effects model, a statistically significant effect size, 0.271 , is identified for the benefit of female teachers. According to the classifications of Cohen [58] and Thalheimer and Cook [59], this result is on the low level. When these results are evaluated together, it can be said that there is a low level of difference with regard to gender variable concerning the ATTPs of preservice teachers. As no meta-analysis study exists on the ATTPs of students with regard to gender, the opportunity to compare these results is not in question.

In the research carried out by $[27,28,29,30,31,32,33,34,35,36,37,38,40,49,53,60,61,62,63$, $64,65]$ the finding for the benefit of females that there is a difference between the opinions concerning ATTPs with regard to the genders of teachers is supported by the results of this meta-analysis. Accordingly, it can be said that although on a lower level, the ATTPs of female teachers are more positive compared to male teachers. Within the scope of the results of this study, it can be stated that female teachers display more positive attitudes compared to male teachers and the idea that the teaching profession is more appropriate for females can be effective in such a situation. Besides finding that the teaching profession is regarded as an appropriate profession for females [66], it can be evaluated as one of the reasons for their higher ATTPs that female preservice teachers think that they can run family and work life together. In a report by TEDMEM named "Teaching Profession from the Eyes of Teachers," it is stated that the attitudes of female teachers towards their occupation are more positive compared to male teachers. This result demonstrates that attitudes of female preservice teachers are qualitatively better than males when they begin to perform their profession. According to the TEDMEM report, the teaching profession being a rewarding and reputable occupation; the idea that being a teacher gives meaning to the personality and occupation; and, its being among the respected occupations in society, contribute to the positive ATTPs of female teachers. The ideas that teachers are perceived as individuals who guide society, and the idea that the teaching profession is an ideal occupation, are among the reasons that encourage female teachers to enter the profession [64]. The attitudes of female teachers towards their occupation are thought to be positively influenced by their being able to practise their occupation under state guarantee; their being considered important by both students and parents of students; and that their working hours are appropriate.

Contrary to the findings of the research, in a study conducted by Eraslan and Çakıcı [67], it is identified that the ATTPs of male students are more positive compared to female students. Also, in studies conducted by Bayhan [68],
Bulut [30], Kaplan and İpek [69], it is observed that there is no significant difference between the ATTPs of female and male teachers, and female and male preservice teachers.

When branches are considered, it is observed that the ATTPs of students in pre-school and classroom teaching departments are better compared to students in other branches. Such a situation can arise from the fact that the numbers of female teachers who prefer pre-school and classroom teaching branches are higher compared to other branches.

According to the regions of the cities where the research was conducted, when the results of the studies carried out in South-eastern Anatolia and Black Sea Regions are analysed, it is observed that the ATTPs of female teachers are more positive. In the research carried out by Çiçek Sağlam [35], and Tekerek and Polat [15] in South-eastern Anatolia, and in the research carried out by Çiğdem and Memiş [36] in Black Sea Region, it was found out that the ATTPs of female teachers are more positive compared to male teachers; and this result supports the results of this study. The reason for this may be the prevalence of more traditional attitudes in these areas, and which typically result in fewer females being educated. Fewer female students have the opportunity for university education, and young women may instead choose to join the teaching profession, which is respected in society. Taken together these factors might positively affect the attitudes of women in Turkey towards the occupation.

When the results of the research are analysed, it is observed that as class levels of female preservice teachers' increase, their ATTP become more positive. This result shows similarities with the results of the research conducted by Çiçek Sağlam [35], Hoşgörür, Kılıç and Dündar [70]. It can be said that from senior classes onwards, teaching practices increase and students learn the teaching profession more closely, and their attitudes develop, such factors support the improvement of their attitudes.

The reasons for why there is a low level of difference with regard to the gender variable concerning ATTP of preservice teachers, and the fact that although on a lower level, ATTPs of females are more positive compared to males should be found out and discussed. It may be that males require additional support or that in general all preservice teachers can be better supported, with the aim of enhancing their attitudes towards their occupation. This research is limited to the attitudes of preservice teachers and similar work could be conducted throughout the profession. Apart from the gender variable of teachers, other meta-analysis studies with regard to ATTP can be carried out using variables such as predictor marital status, and working in private/public institutions.

\section{REFERENCES}

[1] Katkat, D. and Mızrak, O. (2003). Öğretmen adaylarının pedagojik eğitimlerinin problem çözme becerilerine etkisi. [The effect of problem-solving skills of pedagogical training 
of prospective teachers]. Milli Eğitim Dergisi, Vol. 158 Ankara.http://dhgm.meb.gov.tr/yayimlar/dergiler/Milli_Egiti m_Dergisi/158/k atkat.htm, (ET: 11.05.2012).

[2] Celep, C. (2004). Meslek olarak ögretmenlik. [Teaching as a profession]. Edit. C. Celep, Ankara: Anı Yayınc1lık.

[3] Kavcar, C. (1982). "Tarihe karışan bir öğretmen yetiştirme modeli: Yüksek ögretmen okulu". [A teacher training model involved History]. Ankara Üniversitesi Eğitim Fakültesi Dergisi. 15(1), 197-214.

[4] Yıldırım, N. (2014). Meta analiz. Metin, M. (Ed.), Kuramdan uygulamaya eğitimde bilimsel araștırma yöntemleri [Research methods in education from theory to practice]. (137- 159), Ankara: Pegem Akademi.

[5] Hacıömeroğlu, G. \& Şahin Taşkın, Ç. (2010). Fen bilgisi öğretmenliği ve ortaöğretim fen ve matematik alanları (OFMA) eğitimi bölümü öğretmen adaylarının öğretmenlik mesleğine ilişkin tutumları. [Preservice teachers' attitudes towards teaching profession in primary and secondary education]. Ahi Evran Üniversitesi Eğitim Fakültesi Dergisi, $11(1), 77-90$.

[6] Pehlivan, K. B. (2008). Sınıf öğretmeni adaylarının sosyo-kültürel özellikleri ve öğretmenlik mesleğine yönelik tutumları üzerine bir çalıșma. [Teacher candidates a study on the socio-cultural characteristics and attitudes towards the teaching profession]. Mersin Üniversitesi Eğitim Fakültesi Dergisi, 4(2), 151-168.

[7] Çeliköz, N. \& Çetin, F. (2004). Anadolu öğretmen lisesi öğrencilerinin öğretmenlik mesleğine yönelik tutumlarını etkileyen etmenler. [Factors affecting the attitudes towards teaching profession of the Anatolian teacher high school students]. Milli Ĕgitim Dergisi, 162(1), 139-157.

[8] Ak1ll, M. \& Seven, S. (2010). An investigation of prospective science teachers' attitudes towards the profession of teaching. Inönü University Journal of the Faculty of Education, 11(3), 61-73.

[9] Semerci, N. \& Semerci, Ç. (2004). Türkiye'de öğretmenlik tutumlar1. [Teachers attitudes in Turkey]. Firat Universitesi Sosyal Bilimler Dergisi, 14(1), 137-146.

[10] Gürbüz, H. \& Kışoğlu, M. (2007). Tezsiz yüksek lisans programına devam eden fen-edebiyat ve eğitim fakültesi öğrencilerinin öğretmenlik mesleğine yönelik tutumları (Atatürk Üniversitesi örneği). [Attitudes of The Science And Art Faculty Students and Education Faculty Students Attend The Non- Thesis Graduated Education Program Toward Teaching Profession (Atatürk University Sample)]. Erzincan Eğitim Fakültesi Dergisi, 9 (2), 71-83.

[11] Temizkan, M. (2008). Türkçe öğretmeni adaylarının öğretmenlik mesleğine yönelik tutumları üzerine bir araştırma. [An evaluation on the attitudes of Turkish teacher candidates their professions]. Türk Eğitim Bilimleri Dergisi, 6 (3), 461-486.

[12] Durmuşoğlu, M. C.; Yanık, C. \& Akkoyunlu B. (2009). Türk ve Azeri öğretmen adaylarının öğretmenlik mesleğine yönelik tutumlar1. [Turkish and Azerbaijani prospective teachers' attitudes to their profession]. Hacettepe Üniversitesi Ë̆itim Fakültesi Dergisi, 36: 76-86.

[13] Sezer, A., Pınar, A. \& Yıldırım, T. (2010). Coğrafya öğretmeni adaylarının bazı profil özellikleri ve öğretmenlik mesleğine yönelik tutumlarının incelenmesi. [An investigation of geography student teachers' profiles and attitudes toward teaching profession)]. Marmara Coğrafya Dergisi, 22, 43 69.

[14] Üstüner, M. (2006). Öğretmenlik mesleğine yönelik tutum ölçeğinin geçerlik ve güvenirlik çalışması. [Reliability And Validity Study Of An Attitude Scale of Teaching Profession]. Kuram ve Uygulamada Eğitim Yönetimi, 12 (1), 109-127.

[15] Tekerek, M. \&Polat, S. (2011). Öğretmen adaylarının ögretmenlik mesleğine ilişkin tutumları. [Teacher attitudes of the candidates for the teaching profession]. 5. Uluslararas1 Bilgisayar ve Öğretim Teknolojileri Sempozyumu, 22-24 Eylül, Firat Üniversitesi, Elazığ

[16] Aytaç, T. (2014). The effect of school type on intimidation (mobbing) experienced by teachers in schools: A meta-analysis. Educational Research and Reviews, 9(20), 1055- 1064. doi: 10.5897/ERR2014.1882.

[17] Cumming, G. (2012). Understanding the new statistics. New York: Routledge, Taylor and Francis Group

[18] Kış, A. (2013). Okul müdürlerinin öğretimsel liderlik davranışlarını gösterme düzeylerine ilişkin yönetici ve öğretmen görüsslerine yönelik bir meta-analiz. [The views of administrators and teachers on levels of principals instructional leadership behaviours: A meta-analysis]. Unpublished doctoral thesis. Inönü Üniversitesi Eğitim Bilimleri Enstitüsü, Malatya.

[19] Yıldirım, N. (2014). Meta analiz. [Meta-analysis]. Metin, M. (Ed.), Kuramdan uygulamaya eğitimde bilimsel araştırma yöntemleri (137-159), Ankara: Pegem Akademi.

[20] Ipek, C., Aytaç, T. \& Gök, E. (2015). Effect of gender on teachers' organizational culture perception: a meta-analysis. Journal of Education and Training Studies, 3(4), 9-20. doi:10.11114/jets.v3i4.747.

[21] DeCoster J. (2004). Meta-analysis notes. Department of Psychology, University of Alabama.

[22] Petitti, D. B. (2000). Meta-analysis, decision analysis, and cost-effectiveness analysis (2nd ed.). New York: Oxford University Press.

[23] Borenstein, M., Hedges, L. V., Higgins, J. P. T., \& Rothstein, H. R. (2009). Introduction to meta-analysis. West Sussex-UK: John Wiley \& Sons Ltd.

[24] Dinçer, B. (2013). Ilköğretim matematik öğretmen adaylarının mesleğe karşı tutum, algı ve umutsuzluk düzeylerinin incelenmesi. [A study of preservice teachers attitude,perception and hopelessness levels towards their professions]. Unpublished master thesis. Dokuz Eylül Üniversitesi Eğitim Bilimleri Enstitüsü, Izmir.

[25] Yılmaz, K., Altınkurt, Y., \&Yıldırım, H. (2015). Türkiye'deki öğretmenlerin örgütsel vatandaşlık davranışlarına cinsiyet, kıdem ve branş değişkenlerinin etkisi: bir meta analiz çalışması. [The effects of gender, seniority and subject matter variables on teachers' organizational citizenship behaviors in Turkey: A meta-Analysis]. Eğitim ve Bilim, Cilt 40, Sayı 178, 285-304.

[26] Petticrew M., Roberts H. (2006) Systematic Reviews in the Social Sciences: A practical guide. Oxford: Blackwell Publishing.

[27] Akkaya, N. (2009). Öğretmen adaylarının öğretmenlik mesleğine yönelik tutumlarının bazı değişkenlere göre 
incelenmesi. [An investigetion of prospective teachers' attitudes regarding teaching various in terms of variables] Dokuz Eylül Üniversitesi Buca Eğitim Fakültesi Dergisi, 25, $35-42$.

[28] Akpınar, E.; Yıldız, E. \& Ergin, Ö. (2006). Fen bilgisi öğretmen adaylarının öğretmenlik mesleğine karşı tutumları. [Science teachers' attitudes towards the profession of teaching]. Dokuz Eylül Üniversitesi Buca Eğitim Fakültesi Dergisi, 19, 56-62.

[29] Aydın, R. \& Sağlam, G. (2012). Öğretmen adaylarının öğretmenlik mesleğine yönelik tutumlarının belirlenmesi (Mehmet Akif Ersoy Üniversitesi örneği). [Teacher applicant's view directed towards to profession of teacher (Example of Mehmet Akif Ersoy University)]. Türk Eğitim Bilimleri Dergisi,10(2), 257-294.

[30] Bulut, D. (2011). Müzik öğretmeni adaylarının öğretmenlik mesleğine yönelik tutumları. [Attitudes of music teacher candidates towards the profession of teaching]. Gazi Ĕgitim Fakültesi Dergisi, 31(3), 651-674. Cohen, J. (1988). Statistical power analysis for the behavioral sciences (2 nd. edition). New Jersey: Lawrence Erlbaum Associates, Inc.

[31] Çeliköz, M. (2010). Giyim öğretmen adaylarının öğretmenlik mesleğine yönelik tutumlarının bazı değişkenler açısından incelenmesi. [Examining some of the variables in terms of clothing teachers ' attitudes towards the teaching profession]. Unpublished master thesis. Selçuk Üniversitesi Giyim Endüstrisi ve Giyim Sanatları Eğitimi Bölümü, Konya.

[32] Çapri, B. ve Çelikkaleli, Ö., (2008). Öğretmen adaylarının öğretmenliğe ilişkin tutum ve mesleki yeterlik inançlarının cinsiyet, program ve fakültelerine göre incelenmesi. [Investigation of preservice teachers' attitudes towards teaching and professional selfefficacy beliefs according to their gender, programs, and faculties]. Inönü Üniversitesi Ĕ̈itim Fakültesi Dergisi, 15, 33-53.

[33] Çetinkaya, R. (2007). Türkçe öğretmeni adaylarının yeterlilik algıları ve öğretmenlik mesleğine yönelik tutumları. [Qualification perception of the Turkish teacher candidates and attitudes to teaching occupation]. Unpublished master thesis. Selçuk Üniversitesi Sosyal Bilimler Enstitüsü, Konya. *Çetinkaya, Z. (2009). Identifying Turkish pre-service teachers' attitudes toward teaching profession. Elementary Education Online, 8(2), 298-305.

[34] Çetinkaya, Z. (2009). Identifying Turkish pre-service teachers' attitudes toward teaching profession. Elementary Education Online, 8(2), 298-305.

[35] Çiçek Sağlam, A. (2008). Müzik öğretmenliği bölümü öğrencilerinin öğretmenlik mesleğine yönelik tutumları. [The attitudes of the branch of music students toward the teaching profession]. Yüzüncü Yll Üniversitesi Ĕ̈itim Fakültesi Dergisi, 5(1), 59-69.

[36] Çiğdem, G. \& Memiş, A. (2011). Sınıf öğretmenliği adaylarının öğrenme stilleri ve öğretmenlik mesleğine yönelik tutumlarının çeşitli değişkenler açısından incelenmesi. [Examination candidates' classroom teaching and learning styles, attitudes towards the teaching profession in terms of various variables]. Çukurova Üniversitesi Eğitim Fakültesi Dergisi, 3(40), 57-77.

[37] Çiğdem, G. (2010). Sinıf öğretmenliği adaylarının öğrenme stilleri ve öğretmenlik mesleğine yönelik tutumlarının çeşitli değişkenler açısından incelenmesi. [Learning styles of the primary school teacher candidates and the research on attitudes towards teaching for profession in terms of various factors]. Unpublished master thesis. Zonguldak Karaelmas Üniversitesi Sosyal Bilimler Enstitüsü, Zonguldak.

[38] Dağ, E. (2010). Sınıf öğretmeni adaylarının öğretmenlik mesleğine yönelik tutumları ile öğretmenlik mesleğini tercih etmelerinde etkili olan faktörler arasındaki ilişki (Izmir ili örneği). [The relationship between the candidate elementary teachers' attitudes for becoming teachers and the factors affecting their preferences for this occupation]. Unpublished master thesis. Ege Üniversitesi Sosyal Bilimler Enstitüsü, Izmir.

[39] Derman, A. (2007). Kimya öğretmeni adaylarının öz yeterlik algıları ve öğretmenlik mesleğine yönelik tutumları. [Chemistry student teachers' self-efficacy beliefs and attitudes toward teaching profession]. Unpublished doctoral thesis. Selçuk Üniversitesi Fen Bilimleri Enstitüsü, Konya.

[40] Gür Erdoğan, D. \& Güneş, Z. D. (2012). Sakarya Üniverstesi Eğitim Fakültesi birinci sınıf öğrencilerinin öğretmenlik mesleğine karşı tutumları. [The attitudes of first grade students' towards teaching profession at education faculty of Sakarya University]. Uludă̆ Üniversitesi Ĕ̆itim Fakültesi Dergisi, 25(1), 51-62.

[41] Gökçe, F. \& Sezer, G. O. (2012). Öğretmen adaylarının ögretmenlik mesleğine yönelik tutumları (Uludağ Üniversitesi örneği). [The attitudes of student teachers towards teaching profession: Uludağ University sample]. Uludağ Üniversitesi Eğitim Fakültesi Dergisi, 25(1), 1-23.

[42] Gülsoy, F. (2010). Marmara Üniversitesi Eğitim Fakültesi fizik öğretmenliği öğrencilerinin öğretmenlik mesleğine ilişkin tutumları. [The attitiude of the students in the department of teaching physics in Marmara University towards teaching]. Unpublished master thesis. Marmara Üniversitesi Eğitim Bilimleri Enstitüsü, Istanbul.

[43] Kartal, T., Kaya, V. H., Öztürk, N. \& Ekici, G. (2012). The exploration of the attitudes of the science teacher candidates towards teaching profession. Procedia - Social and Behavioral Sciences, 46, 2759 -2764. doi: 10.1016/j.sbspro.2012.05.561.

[44] Kaya, K. (2004). Beden eğitimi ve spor yüksekokulu ögrencilerinin öğretmenlik mesleğine karşı tutumları. [The attitudes of physical education and sports high school students towards the prefession of teaching]. Unpublished master thesis. Gazi Üniversitesi Ĕgitim Bilimleri Enstitüsü, Ankara.

[45] Ertok Konuk, N. (2011). Müzik öğretmeni adaylarının öğretmenliğe ilişkin tutum ve mesleki yeterlik alg1 düzeylerinin farklı değișkenlere göre incelenmesi. [Examination of the behavior and professional adequacy of the music teacher candidates towards preceptorship regarding several variables]. Unpublished doctoral thesis. Marmara Üniversitesi Eğitim Bilimleri Enstitüsü, Istanbul.

[46] Oğuz, E. \& Kalkan, M. (2011). Examining teacher candidates' attitudes towards teaching profession and pupil control ideology. International Online Journal of Educational Sciences, 3(3), 903-917.

[47] Özder, H., Konderalı, G. \& Perkan Zeki, C. (2010). Öğretmen adaylarının öğretmenlik mesleğine yönelik tutumlarının çeşitli değişkenler açısından incelenmesi. [Examining the attitudes towards the teaching profession and academic 
achievements of prospective teachers]. Kuram ve Uygulamada Eğitim Yönetimi, 16(2), 253-275.

[48] Pehlivan, K.B. (2010). A study on prospective teachers' learning styles and their attitudes toward teaching profession. Elementary Education Online, 9(2), 749-763.

[49] Pektaş, M. \& Kamer, S.T. (2011). Fen bilgisi öğretmen adaylarının öğretmenlik mesleğine yönelik tutumları. [The attitudes of science teacher trainees for teaching profession]. Türk Ĕ̈itim Bilimleri Dergisi, 9(4), 829-850.

[50] Serin, O.; Serin, U. I; Saracaloğlu, A.S. \& Kesercioğlu, T. (2004). Fen grubu öğretmen adaylarının mesleğe yönelik tutumlarının karşılaştırılması. [The comparison of science teacher candidates attitudes towards the teaching profession]. Marmara Üniversitesi Atatürk Eğitim Fakültesi Eğitim Bilimleri Dergisi, 19, 121-136.

[51] Sezer, A. ; Pınar, A. \& Yıldırım, T. (2010). Coğrafya öğretmeni adaylarının bazı profil özellikleri ve öğretmenlik mesleğine yönelik tutumlarının incelenmesi. [An Investigation of Geography Student Teachers' Profiles and Attitudes Toward Teaching Profession]. Marmara Coğrafya Dergisi, 22, 43 - 69 .

[52] Tanel, R.; Kaya Şengören, S. \& Tanel, Z. (2007). Fizik öğretmen adaylarının öğretmenlik mesleğine ilişkin tutumlarının farklı değişkenler açısından incelenmesi. [Investigating attitudes of prospective physics teachers towards teaching as a profession regarding various variables.] Pamukkale Üniversitesi Eğitim Fakültesi Dergisi, 22, 1-9.

[53] Tekneci, E. (2010). Zihin engelliler öğretmenliği 1. ve 4. sınıf öğrencilerinin öğretmenlik mesleğine yönelik tutumları ile kaygı düzeylerinin karşılaştırılması. [Attitudes of 1st and 4th grade university students attending mentally disabled education towards teaching profession and comparison of their anxiety levels]. Unpublished master thesis. Marmara Üniversitesi Eğitim Bilimleri Enstitüsü, Ankara.

[54] Uğurlu, C.T. \& Polat, S. (2011). Sinıf öğretmenliği öğrencilerinin öğretmenlik mesleğine ilişkin tutumları. [The attitudes of elementary education students towards teaching profession]. Cumhuriyet Üniversitesi Sosyal Bilimler Dergisi, 35 (1), 68-74.

[55] Üstüner, M., Demirtaş, H. \& Cömert, M. (2009). Öğretmen adaylarının öğretmenlik mesleğine yönelik tutumları (Đnönü Üniversitesi Eğitim Fakültesi örneği). [The attitudes of prospective teachers towards the profession of teaching (The case of Inonu University, Faculty of Education)]. Eğitim ve Bilim, 34 (151), 140-155.

[56] Yeşil, H. (2011). Turkish language teaching students' attitudes towards teaching profession. International Online Journal of Educational Sciences, 3 (1), 200-219. Yıldırım, A. (2011). Öğretmen eğitiminde çatışma alanları ve yeniden yapılanma. [Competing agendas and reform in teacher education]. Uluslararası Ĕgitim Programları ve Öğretim Çalışmaları Dergisi, 1(1), 1-17.

[57] Y1lmaz, S. Ş. (2009). Okul öncesi öğretmen adaylarının mesleki tutumları ile kişisel değerleri arasındaki ilişkinin incelenmesi. [Analysis of the relationship between preschool candidate teachers' the professional attitudes and personal values]. Yayımlanmamış yüksek lisans tezi. Abant Izzet Baysal Üniversitesi Sosyal Bilimler Enstitüsü, Bolu.
[58] Cohen, J. (1988). Statistical power analysis for the behavioral sciences ( 2 nd. edition). New Jersey: Lawrence Erlbaum Associates, Inc.

[59] Thalheimer, W., \& Cook, S. (2002). How to calculate effect sizes from published research articles: A simplified methodology. http://work- learning.com/effect_sizes.htm: 20 January 2014.

[60] Aksoy, M. E., (2010). Öğretmen adaylarının öğretmenlik mesleğine ilişkin tutumları. [Attitudes of preservice teachers' towards profession teaching]. Sosyal Bilimler Araştırma Dergisi, 2, 197-212.

[61] Bozdoğan A. E., Aydın, D., ve Yıldırım K. (2007). Öğretmen adaylarının öğretmenlik mesleğine ilişkin tutumları. [Attitudes of teacher candidates towards teaching profession]. Ahi Evran Üniversitesi Ĕ̈itim Fakültesi Dergisi (KEFAD), 8(2), 83-97.

[62] Doğan, S. (2013). Sınıf öğretmenlerinin öz yeterlik algısı ve öğretmenlik mesleğine yönelik tutumlarının incelenmesi (Ağr1 ili örneği). [Research is analysis of primary school teachers' per-ception of self-efficacy attitude for teachership: Example of Ağrı]. Unpublished master thesis. Erzincan Üniversitesi Sosyal Bilimler Enstitüsü, Erzincan.

[63] Köğçe, D., Aydın, M., ve Yıldız, C. (2009). Birinci ve dördüncü sınıf matematik öğretmen adaylarının öğretmenlik mesleğine karşı tutumlarının karşılaştırması. [Comparison of attitudes towards the teaching profession in the first and fourth grade math teachers]. Karadeniz Teknik Üniversitesi Eğitim Bilimleri Dergisi, 19, 60-63.

[64] TEDMEM, (2014). "Öğretmen gözüyle öğretmenlik mesleği” raporu. [Teachers eye of the teaching profession]. TED Yayınları.

[65] Yüksel, S., (2004). Tezsiz yüksek lisans programının öğrencilerin öğretmenlik mesleğine ilişkin tutumlarına etkisi. [The effects of the non-thesis master's program on students' attitudes towards the teaching profession]. Uludağ Üniversitesi Eğitim Fakültesi Dergisi, 17 (2), 355-37.

[66] Saban, A. (2003). A Turkish profile of prospective elementary school teachers and their views of teaching. Teaching and Teacher Education, 19 (8), 829-846. doi:10.1016/j.tate.2003. 03.004 .

[67] Eraslan, L. ve Çakıcı, D. (2011). Pedagojik formasyon programı öğrencilerinin öğretmenlik mesleğine yönelik tutumları. Kastamonu Ĕ̆itim Dergisi, 2, 427-438.

[68] Bahyan, P. (2009). Ilköğretim okulları birinci kademe sinıf ögretmenlerinin ögretmenlik mesleğine yönelik tutumlart ile iș doyumları arasındaki ilișki. Yayımlanmamıș Yüksek Lisans Tezi. Yeditepe Üniversitesi Sosyal Bilimler Enstitüsü, İstanbul.

[69] Kaplan, A. \& İpek, A. S. (2002). Matematik öğretmenliği adaylarının öğretmenlik mesleğine yönelik tutumlarının incelenmesi. Ĕgitim ve Bilim Dergisi, 27(125), 69-73.

[70] Hoşgörür, V., Kılıç, Ç. \& Dündar, H. (2002). Kırıkkale Üniversitesi sınıf öğretmenliği programı öğrencilerinin öğretmenlik mesleğine karşı tutumları. [Attitudes of Kirıkkale Unıversity elementary education students to profession of teaching]. Marmara Üniversitesi Atatürk Ĕ̈itim Fakültesi Ĕ̆itim Bilimleri Dergisi, 16, 91-100. 